\title{
The hormonal receptor status of uterine carcinosarcomas (mixed Müllerian tumours): an immunohistochemical study
}

\author{
A C Ansink, P A Cross, P Scorer, A de Barros Lopes, J M Monaghan
}

\begin{abstract}
Aim-To investigate the role of oestrogen and progesterone receptor status in uterine carcinosarcomas (mixed Müllerian tumours) to see whether the receptors were identifiable, and if so whether they were of significance clinically.

Methods-11 cases of uterine carcinosarcoma were identified from clinical and pathology records. An immunohistochemical method was used to demonstrate oestrogen and progesterone hormone receptors on paraffin embedded material, with suitable tissue controls, staining being recorded.
\end{abstract}

Results-10 of 11 cases showed staining for one or both hormone receptors in normal tissue adjacent to tumour. In four carcinosarcoma cases, staining for one or both receptors was shown within the epithelial component (appearing to correlate with the degree of epithelial differentiation); two of these cases had staining within sarcomatous areas. Two of the three patients still alive had epithelial hormone receptor positivity.

Conclusions-Receptors for oestrogen and progesterone were found in four of 11 cases of uterine carcinosarcoma, using paraffin embedded material. There may be an association between hormone receptor positivity and clinical outcome. (F Clin Pathol 1997;50:328-331)

Keywords: hormonal receptor status; uterine mixed Müllerian tumours; uterine carcinosarcomas

Queen Elizabeth

Hospital, Sheriff Hill, Gateshead, Tyne and Wear:

Department of Gynaecological Oncology

A C Ansink

A de Barros Lopes

J M Monaghan

Department of Pathology

P A Cross

P Scorer

Correspondence to: Dr P A Cross, Department of Pathology, Queen Elizabeth Hospital, Sheriff Hill, Gateshead, Tyne and Wear NE9 6SX, United Kingdom.

Accepted for publication 22 January 1997 reports on the response to hormone treatme in these latter tumours have now been published. ${ }^{4-9}$ Most papers on the hormone receptor status of uterine sarcomas have concentrated on endometrial stromal sarcomas. ${ }^{70-13}$ In some studies of gynaecological malignancies hormone receptors have been investigated in homogenised tissue, ${ }^{267}$ while in others tissue sections have also been examined immunohistochemically. ${ }^{1-3}$ Recent reports have suggested that prognosis in carcinosarcomas (mixed Müllerian tumours) may be related to the epithelial component, ${ }^{14}{ }^{15}$ and it has also been suggested that the epithelial component in other gynaecological tumours is hormone dependent. $^{1-3}$ In light of these findings we decided to look for evidence of hormone receptors in uterine carcinosarcomas, and if they were present, whether the pattern and type of staining bore any relation to tissue components within the tumours or to clinical outcome.

\section{Methods}

PATIENTS

The databases of the departments of gynaecological oncology and histopathology at the Queen Elizabeth Hospital, Gateshead, were searched for cases of uterine carcinosarcoma. Of the cases identified, only 11 had sufficient histological material for the study. These comprised nine heterologous and two homologous uterine carcinosarcomas (tables 1 and 2).

Clinicopathological details are shown in tables 1 and 2. All patients were postmenopausal. One patient died four days postoperatively from a pulmonary embolus. In five patients a lymph node dissection was performed. In two of these, metastases were found.

Of the seven patients who developed recurrent disease, only two had local (pelvic) recurrence. The remaining five patients developed abdominal, hepatic, and pulmonary metastases, in two cases in addition to pelvic recurrence. At the time of writing three patients were alive and well at 12,48 , and 84 months, respectively after primary treatment.

Clinical data regarding age, stage (according to the 1988 FIGO staging for endometrial carcinoma), tumour size, menopausal status, time to recurrence, localisation of recurrence, and current status were collected from the database and the original case notes (AA). The original slides were reviewed by one of the authors (PC). Histopathological data were collected on tumour type and components present, depth of myometrial invasion, mitotic rate, vascular space involvement, and lymph node status.

\section{PROCEDURES}

The paraffin processed blocks of the cases were identified, along with the original sections and reports. Blocks containing the tumour elements as well as those containing normal uterine tissue (if present) were identified. Commercial monoclonal mouse antihuman oestrogen receptor antibody (Dako-ER, 1D5, Dako, Glostrup, Denmark) and mouse monoclonal antihuman progesterone receptor antibody 
Table 1 Clinicopathological details of 11 uterine carcinosarcoma patients

\begin{tabular}{|c|c|c|c|c|c|c|c|c|c|}
\hline Case No & Age (years) & FIGO stage & Tumour size $(\mathrm{cm})$ & $\begin{array}{l}\text { Myometrial } \\
\text { invasion }\end{array}$ & $\begin{array}{l}\text { Vessel space } \\
\text { involvement }\end{array}$ & $\begin{array}{l}\text { Mitoses } / 10 \text { HPF in } \\
\text { sarcomatous areas }\end{array}$ & Recurrence & $\begin{array}{l}\text { Time to } \\
\text { recurrence } \\
\text { (months) }\end{array}$ & Current status \\
\hline 1 & 84 & I & 6 & $>1 / 2$ & No & 21 & Yes & 17 & DOD \\
\hline 2 & 62 & I & 6 & $>1 / 2$ & No & 23 & No & N/A & NED \\
\hline 3 & 59 & I & - & $<1 / 2$ & Yes & 10 & No & N/A & NED \\
\hline 4 & 87 & I & 7 & $>1 / 2$ & Yes & 34 & Yes & 5 & DOD \\
\hline 5 & 77 & I & 5 & $>1 / 2$ & Yes & 16 & No & N/A & Postop death \\
\hline 6 & 66 & IV & 10 & $>1 / 2$ & Yes & 16 & Yes & 4 & DOD \\
\hline 7 & 65 & IV & 11 & $>1 / 2$ & No & 6 & Yes & 8 & DOD \\
\hline 8 & 62 & III & 8 & $>1 / 2$ & Yes & 6 & Yes & 5 & DOD \\
\hline 9 & 64 & I & - & - & No & 15 & Yes & 39 & DOD \\
\hline 10 & 55 & IV & 5 & $<1 / 2$ & Yes & 4 & Yes & 2 & Postop death \\
\hline 11 & 71 & I & 11 & $<1 / 2$ & No & 10 & No & N/A & NED \\
\hline
\end{tabular}

HPF, high power field; DOD, dead of disease; NED, no evidence of disease. -, missing data due to insufficient histological material; N/A, not applicable.

(Novocastra Laboratories, Newcastle upon Tyne) were used, both at working dilutions of $1 / 40$.

The method, in brief, is as follows. Cut sections ( $3 \mu \mathrm{m}$, vectabonded slides) were dewaxed and taken down to water, and then placed in a $0.01 \mathrm{M}$ citrate buffer ( $\mathrm{pH} 6)$ in a Sharp compact $650 \mathrm{~W}$ microwave at the "high" setting for 11 minutes. The sections were removed and allowed to cool for 20 minutes, and the buffer was drained and replaced by Tris buffered saline (TBS), $\mathrm{pH}$ 7.6. Normal swine serum (diluted $1 / 4$ with TBS) was then placed over the sections and left for 10 minutes. The slides were quickly dried, and the primary antibodies (as described above; $50 \mu \mathrm{l}$ ) were added to the section area and left at room temperature for 60 minutes. The slides were then washed with TBS, placed in a TBS bath for five minutes, dried, and the biotinylated secondary antibody (diluted $1 / 100$ with $1 / 4$ TBS; $50 \mu \mathrm{l}$ ) was added to the sections and left for 30 minutes at room temperature. After a second TBS wash and bath cycle, the slides were dried and streptavidin alkaline phosphatase $(1 / 100$ diluted with $1 / 4$ TBS; $50 \mu \mathrm{l})$ was added to the sections for 30 minutes at room temperature. After a final TBS wash and bath cycle, fresh new fuchsin reagent (Dakokit) was prepared and added to the slides for 10 minutes at room temperature. They were then washed in tap water and counterstained in Carazzi's haematoxylin for 15 seconds. Finally sections were washed and blued in Scotts tap water substitute, washed again in water, allowed to air dry, and then dipped in xylene and mounted with DPX and coverslip.

A breast carcinoma control was used, which was positive for both oestrogen and progester- one receptors. A negative control was also used for each case (omitting the primary antibody only). Slides were counted as positive only if nuclear staining was seen, necrotic areas being avoided. Slides were screened with a Leitz Diaplan, using a $\times 40$ objective. At least 250 nuclei were studied in each case. Cases were recorded in a semiquantitative manner after Thornton and Wells, ${ }^{16}$ who used frozen tissue. Cells were scored for nuclear staining from 0 to 3 : 0 , no specific stain; 1 , weak; 2 , moderate; 3 , strong. In addition, a score of 0 to 3 was used for the proportion of cells specifically stained: 0 , $<11 \% ; 1,11-30 \% ; 2,31-60 \%$; $3,>60 \%$. This was performed for each component of the tumour as well as for the normal tissue adjacent to the tumour.

\section{Results}

The results of the oestrogen and progesterone receptor detection are given in table 3 . Normal tissues in these specimens showed positive nuclear staining for at least one receptor in 10 out of 11 cases (fig 1 ).

Most of the tumours were negative for both receptors. Only four cases showed focal positivity for one (or both) receptors (fig 2), and then mainly in the epithelial component of the tumour (one well differentiated endometrioid, two moderately well differentiated endometrioid, and one poorly differentiated serous). Two showed positivity in the sarcomatous area, these being classed as sarcoma not otherwise specifiable.

The positive as well as the negative controls were appropriately stained throughout (fig 3).

Table 2 Tumour elements identified within uterine carcinosarcoma cases studied

\begin{tabular}{|c|c|c|c|c|c|c|c|}
\hline \multirow[b]{2}{*}{ Case No } & \multicolumn{2}{|c|}{ Adenocarcinoma } & \multirow[b]{2}{*}{ Rhabdomyosarcoma } & \multirow{2}{*}{$\begin{array}{l}\text { Poorly } \\
\text { differentiated } \\
\text { sarcoma NOS }\end{array}$} & \multirow{2}{*}{$\begin{array}{l}\text { Squamous cell } \\
\text { carcinoma }\end{array}$} & \multirow[b]{2}{*}{ Chondrosarcoma } & \multirow[b]{2}{*}{ Osteosarcoma } \\
\hline & Endometrioid & Serous & & & & & \\
\hline 1 & $\mathrm{Y}(\mathrm{M})$ & NP & $\mathrm{Y}$ & $\mathrm{Y}$ & $\mathrm{Y}(\mathrm{M})$ & $\mathrm{Y}$ & NP \\
\hline 2 & $\mathrm{Y}(\mathrm{M})$ & NP & NP & $\mathrm{Y}$ & NP & NP & NP \\
\hline 3 & $Y(W)$ & NP & $\mathrm{Y}$ & $\mathrm{Y}$ & NP & $\mathrm{Y}$ & NP \\
\hline 4 & $\mathrm{Y}(\mathrm{M})$ & NP & $\mathrm{Y}$ & $\mathrm{Y}$ & NP & NP & NP \\
\hline 5 & $Y(P)$ & NP & NP & $\mathrm{Y}$ & $\mathrm{Y}(\mathrm{M})$ & NP & NP \\
\hline 6 & $Y(M)$ & NP & $\mathrm{Y}$ & $\mathrm{Y}$ & $\mathrm{NP}$ & NP & NP \\
\hline 7 & NP & $\mathrm{Y}(\mathrm{P})$ & $\mathrm{Y}$ & $\mathrm{Y}$ & NP & NP & NP \\
\hline 8 & $\mathrm{Y}(\mathrm{M})$ & $\mathbf{Y}(\mathbf{M})$ & $\mathrm{Y}$ & $\mathrm{Y}$ & $Y(M)$ & NP & $\mathrm{Y}$ \\
\hline 9 & NP & $Y(P)$ & $\mathrm{Y}$ & $\mathrm{Y}$ & NP & NP & $\mathrm{Y}$ \\
\hline 10 & $\mathrm{Y}(\mathrm{M})$ & NP & $\mathrm{Y}$ & $\mathrm{Y}$ & NP & NP & NP \\
\hline 11 & $\mathrm{Y}(\mathrm{M})$ & NP & $\mathrm{Y}$ & $\mathrm{Y}$ & NP & NP & NP \\
\hline
\end{tabular}

Differentiation: (P), poor; (M), moderate; (W), well differentiated.

NP, not present; Y, present. 


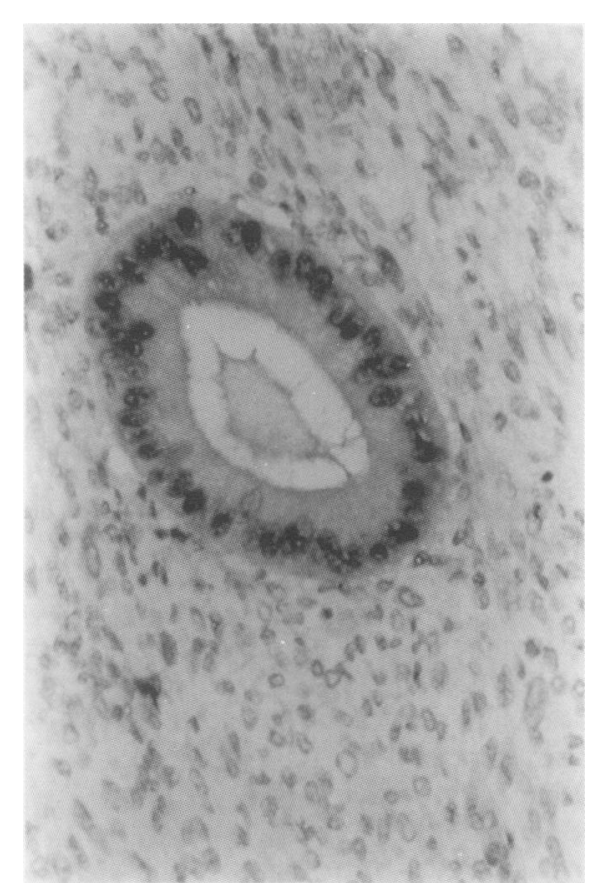

Figure 1 Medium power view of a normal endometrial gland, showing focal weak nuclear positivity for progesterone receptor.

\section{Discussion}

We have shown that in normal tissues, oestrogen and progesterone receptors are present and identifiable using this technique on paraffin embedded material, in line with previous reports. ${ }^{17-19}$ In the majority of the uterine carcinosarcomas studied, however, oestrogen and progesterone receptors were absent.

While tissue fixation may cause problems with immunohistochemical techniques, we feel this is unlikely to have played a major role in this study as all the specimens were fixed and processed in a similar manner, and controls were appropriately used throughout on similarly fixed breast tumour cases.

The majority of tumours were negative, and if positive, only the epithelial element stained. These were in the adenocarcinomatous components (three endometrioid and one serous) and in the sarcomatous area (NOS) in two cases. Two cases stained in both areas. Because of the positive results obtained in normal uterine tissue and in breast cancer tissue controls, it seems unlikely that negative results in tumour

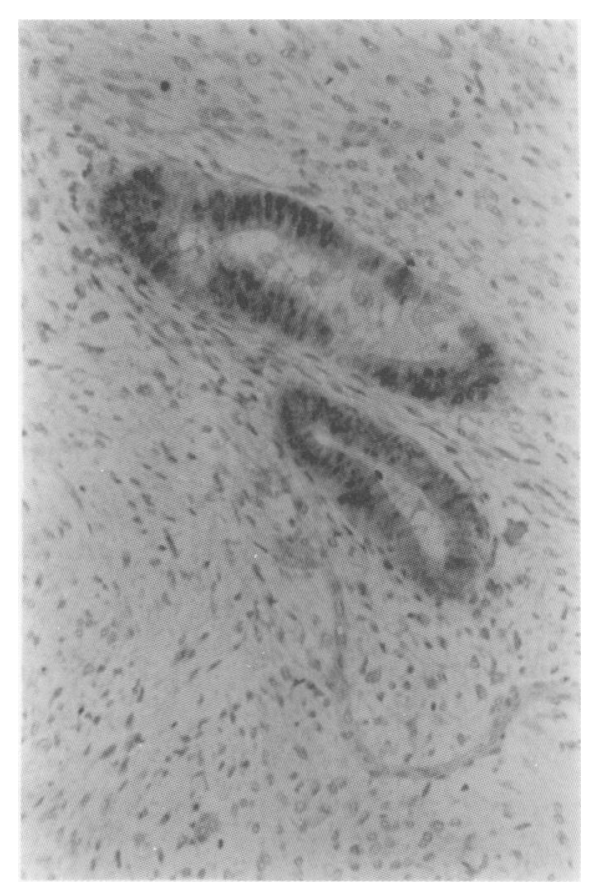

Figure 2 Medium power view of nuclear oestrogen receptor positivity within adenocarcinomatous element of a uterine carcinosarcoma.

tissue in the same cases is related to the technique itself.

Whether patients with hormone receptor positive tumours have a better prognosis remains to be established and the present series is too small to draw any conclusions in this respect. Three out of 11 patients were alive and well at the time of writing. Two of these had hormone receptor positivity in the epithelial uterine carcinosarcoma component, whereas in only two out of eight patients who developed a recurrence and subsequently died of the disease was tumour hormone receptor positivity found (interestingly in both adenocarcinomatous and sarcoma NOS areas). Recently it has been shown that prognosis is correlated with the type and degree of differentiation of the epithelial component in uterine carcinosarcoma. ${ }^{14}$ From our small study there seems to be a trend for patients with better differentiated adenocarcinomatous elements in their tumours to survive longer, but survival does not correlate completely with the receptor status (tables 1 and 3).

Table 3 Oestrogen and progesterone receptor status in normal uterine and tumour elements in 11 uterine carcinosarcoma patients (nuclear staining)

\begin{tabular}{|c|c|c|c|c|c|c|c|c|c|c|c|c|c|c|c|c|}
\hline \multirow{2}{*}{$\begin{array}{l}\text { Case } \\
\text { No }\end{array}$} & \multicolumn{2}{|c|}{ Myometrium } & \multicolumn{2}{|c|}{$\begin{array}{l}\text { Endometrial } \\
\text { glands }\end{array}$} & \multicolumn{2}{|c|}{$\begin{array}{l}\text { Endometrial } \\
\text { stroma }\end{array}$} & \multicolumn{2}{|c|}{ Adenocarcinoma } & \multicolumn{2}{|c|}{$\begin{array}{l}\text { Squamous } \\
\text { carcinoma }\end{array}$} & \multicolumn{2}{|c|}{ Sarcoma NOS } & \multicolumn{2}{|c|}{$\begin{array}{l}\text { Chondrol } \\
\text { osteosarcoma }\end{array}$} & \multicolumn{2}{|c|}{$\begin{array}{l}\text { Rhabdo- } \\
\text { myosarcoma }\end{array}$} \\
\hline & $O$ & $P$ & $O$ & $P$ & $O$ & $P$ & $O$ & $P$ & $O$ & $P$ & $O$ & $P$ & $O$ & $P$ & $O$ & $P$ \\
\hline 1 & NP & NP & $1 / 1$ & $2 / 1$ & $2 / 2$ & $1 / 1$ & - & - & - & - & - & - & - & - & - & - \\
\hline 2 & $2 / 2$ & $3 / 2$ & - & $2 / 1$ & - & $2 / 2$ & - & - & NP & NP & - & - & $\mathrm{NP}$ & NP & $\mathrm{NP}$ & NP \\
\hline 3 & $2 / 2$ & $3 / 2$ & - & $2 / 1$ & - & $2 / 2$ & $3 / 2^{\star}$ & $3 / 3^{\star}$ & NP & NP & _- & - & - & - & - & - \\
\hline 4 & $1 / 2$ & $3 / 3$ & - & $2 / 2$ & - & $2 / 2$ & - & $3 / 1^{\star}$ & NP & NP & - & $3 / 1$ & NP & NP & - & _- \\
\hline 5 & $2 / 2$ & $3 / 2$ & $2 / 3$ & $1 / 2$ & $2 / 2$ & $2 / 2$ & - & - & - & - & - & - & NP & NP & NP & NP \\
\hline 6 & $1 / 1$ & - & - & - & $3 / 3$ & $1 / 2$ & - & - & NP & NP & - & - & NP & NP & - & - \\
\hline 7 & $2 / 2$ & $3 / 2$ & $2 / 1$ & - & $2 / 2$ & $3 / 2$ & - & - & NP & NP & - & - & NP & NP & - & - \\
\hline 8 & - & - & - & - & - & - & - & - & - & - & - & - & - & - & - & - \\
\hline 9 & $1 / 1$ & $1 / 1$ & NP & NP & NP & NP & $2 / 2 \dagger$ & $1 / 1 \dagger$ & NP & NP & $2 / 2$ & $2 / 1$ & - & - & - & - \\
\hline 10 & - & $2 / 2$ & - & - & - & - & - & - & NP & NP & - & - & NP & NP & - & - \\
\hline 11 & - & $3 / 1$ & - & - & - & - & $2 / 1^{\star}$ & - & NP & NP & - & - & NP & NP & - & - \\
\hline
\end{tabular}

$\mathrm{O}$, oestrogen receptor; $\mathrm{P}$, progesterone receptor; $\mathrm{NP}$, not present; -, negative.

First number, intensity of staining ( 0 , no specific staining; 1, weak; 2 , moderate; 3 , strong); second number, proportion of positive cells $(0,<11 \% ; 1,11-30 \% ; 2$, $31-60 \% ; 3,>60 \%)$.

*endometrioid adenocarcinoma; tserous adenocarcinoma. 


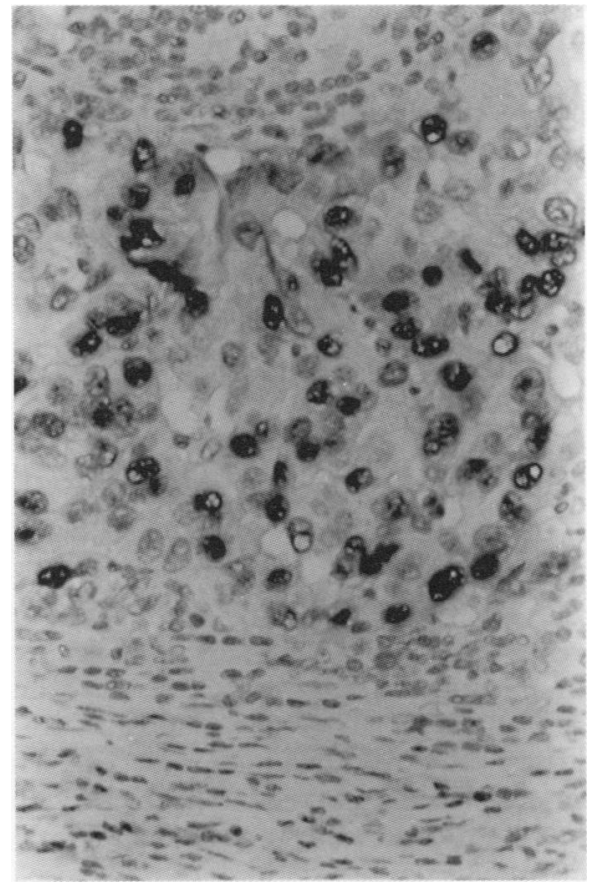

Figure 3 High power view of metastatic breast tumour cells in a lymph node, showing clear nuclear positivity for progesterone receptor.

There is a need to develop new treatments for patients with uterine carcinosarcomas, as current treatment is unsatisfactory. In general, the prognosis of uterine carcinosarcoma is gloomy, even after maximum treatment with surgery, radiotherapy, and chemotherapy. Five year survival for stage I is around $50 \%$, and for advanced disease this figure is $20 \%$. $^{20}{ }^{21} \mathrm{Re}$ ports on uterine malignancies responding to hormone treatment justify further research on the possible therapeutic role of hormonal manipulation in these tumours. It remains to be established whether the presence or absence of hormonal receptors is a key factor in the response to hormonal manipulation. This study was supported by a grant from the Northern Cancer
Care and Research Society, Queen Elizabeth Hospital, Sheriff Care and Research Society, Queen
Hill, Gateshead, Tyne and Wear.

1 Umpierre SA, Burke TW, Tornos C, Ordonez N, Levenback C, Morris M. Immunocytochemical analysis of uterine papillary serous carcinomas for estrogen and progesterone papillary serous carcinomas for estrogen and proge

2 Nyholm HC, Christensen IJ, Nielsen AL. Progesterone receptor levels independently predict survival in endometrial adenocarcinoma. Gynecol Oncol 1995;59:347-51.

3 Nyholm HCJ, Nielsen AL, Lyndrup J, Dreisler A, Thorpe carcinoma: comparison of immunohistochemical and biochemical analysis. Int 7 Gynecol Pathol 1993;12:246-52.

4 O'Brien AA, O'Briain DS, Daly PA. Aggressive endometrial stromal sarcoma responding to medroxyprogesterone following failure of tamoxifen and combination chemotherapy. Case report. Br $\mathcal{F}$ Obstet Gynaecol 1985;92:862-6.

5 Kahanpaa KV, Wahlström T, Gröhn P, Heinonen E, Nieminen $U$, Widholm O. Sarcomas of the uterus: a clinicopathologic study of 119 patients. Obstet Gynecol 1986;67: 417-24.

6 Sutton GP, Stehman FB, Michael H, Young PCM, Ehrlich $\mathrm{CE}$. Estrogen and progesterone receptors in uterine sarcomas. Obstet Gynecol 1986;68:709-14.

7 Katz L, Merino MJ, Sakamoto H, Schwartz PE. Endometrial stromal sarcoma: a clinicopathologic study of 11 cases with determination of estrogen and progestin receptor levels in three tumors. Gynecol Oncol 1987;26:87-97.

8 Wade $\mathrm{K}$, Quin MA, Hammond I, Williams K, Cauchi $M$ Uterine sarcoma: steroid receptors and response to hormonal therapy. Gynecol Oncol 1990;39:364-7.

9 Meden H, Meyer Rath D, Schauer A, Kuhn W. Endometrial stromal sarcomas of the uterus. Anti-cancer Drugs 1991;2: 35-7.

10 Dunton CJ, Kelsten ML, Brooks SE, Viglione MJ, Carlson JA, Mikuta JJ. Low-grade stromal sarcoma: DNA flow cytometric analysis and estrogen progesterone receptor data. Gynecol Oncol 1990;37:268-75.

11 Navarro D, Cabrera JJ, Leon L, Chirino R, Fernandez L, Lopez A, et al. Endometrial stromal sarcoma expression of estrogen receptors, progesterone receptors and estrogeninduced $\operatorname{srp} 27(24 \mathrm{~K})$ suggests hormone responsiveness. $\mathcal{F}$ Steroid Biochem Mol Biol 1992;41:589-96.

12 Sabini G, Chumas JC, Mann WJ. Steroid hormone receptors in endometrial stromal sarcomas. A biochemical and immunohistochemical study. $\mathrm{Am}$ f Clin Pathol 1992;97:381-6.

13 Tosi P, Sforza V, Santopietro R. Estrogen receptor content, immunohistochemically determined by monoclonal antibodies, in endometrial stromal sarcoma. Obstet Gynecol 1989;73:75-8

14 Gagne E, Tetu B, Blondeau L, Raymond PE. Morphologic prognostic factors of malignant mixed mullerian tumour of the uterus (MMMT): a clinicopathologic study of 58 cases. Mod Pathol 1989;2:433-8.

15 George E, Lillemoe TJ, Twiggs LB, Perrone T. Malignant mixed Mullerian tumour versus high-grade endometrial carcinoma and aggressive variants of endometrial carcinoma: a comparative analysis of survival. Int $f$ Gynecol Pathol 1995;14:39-44.

16 Thornton JG, Wells $M$. Oestrogen receptor in glands and stroma of normal and neoplastic human endometrium: a combined biochemical, immunohistochemical, and morphometric study. $\mathcal{F}$ Clin Pathol 1987;40:1437-42.

17 Snijders MPML, De Goeij AFMP, Debets-te Baerts MJC Rousch MJM, Koudstaal J, et al. Immunocytochemical analysis of oestrogen receptors and progesterone receptors in the human uterus throughout the menstrual cycle and after the menopause. $\mathcal{F}$ Reprod Fertil 1992;94:363-71.

18 Nisolle M, Casanas-Rouw F, Wyns C, De Menten Y, Mathieu P-E, Donnez J. Immunohistochemical analysis of estrogen and progesterone receptors in endometrium and peritoneal endometriosis: a new quantitative method. Fertil Steril 1994;62:751-9.

19 Kerner H, Sabo E, Friedman M, Beck D, Samare O, Lichtig C. An immunohistochemical study of estrogen and progesterone receptors in adenocarcinoma of the endometrium and in the adjacent mucosa. Int $\mathcal{f}$ Gynecol Cancer 1995;5:275-81.

20 Major FJ, Blessing JA, Silverberg SG, Morrow CP, Creasman WT, Currie JL, et al. Prognostic factors in earlystage uterine sarcoma. Cancer 1993;71:1702-9.

21 Olah KS, Dunn JA, Gee H. Leiomyosarcomas have a poorer prognosis than mixed mesodermal tumours when adjusting for known prognostic factors: the result of a retrospective study of 423 cases of uterine sarcoma. Br $\mathcal{F}$ Obstet Gynaecol 1992;99:590-4. 